Opting Back In 



\section{Opting Back In}

What Really Happens When Mothers Go Back to Work

Pamela Stone and Meg Lovejoy

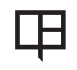


University of California Press

Oakland, California

(C) 2019 by The Regents of the University of California

Library of Congress Cataloging-in-Publication Data

Names: Stone, Pamela, author. | Lovejoy, Meg, author.

Title: Opting back in : what really happens when mothers go back to work / Pamela Stone and Meg Lovejoy.

Description: Oakland, California : University of California Press, [2019] | Includes bibliographical references and index.

Identifiers: LCCN 2019006654 (print) | LCCN 2019009633 (ebook) | ISBN 9780520964792 () | ISBN 9780520290808 (cloth : alk. paper)

Subjects: LCSH: Women-Employment re-entry-United States. | Work and family-United States. | Choice (Psychology) | Life change events.

Classification: LCC HD6054.2.U6 (ebook) | LCC HD6054.2.U6 S76 2019 (print) | DDC 33. $4 / 40973$ - dc23

LC record available at https://lccn.loc.gov/2019006654

Manufactured in the United States of America

$\begin{array}{llllllll}26 & 25 & 24 & 23 & 22 & 21 & 20 & \text { I9 }\end{array}$

IO $\quad \begin{array}{lllllllll}9 & 8 & 7 & 6 & 5 & 4 & 3 & 2 & \text { I }\end{array}$ 


$$
\text { In memory of Ruth Sidel }
$$

For her heart, smarts, wit, and integrity, and for the gentle mentorship that advanced so many women's

$$
\text { careers, including my own }
$$

Pamela Stone

For my mother

Determined, impassioned - a forerunner and role model Meg Lovejoy 

Don't think about making women fit the world-think about making the world fit women.

Gloria Steinem 
